\title{
Correlation Studies in Hybrid Rice (Oryza sativa L.)
}

\author{
B.S. Thorat ${ }^{1}$, R.L. Kunkerkar ${ }^{2}$, S.M. Raut ${ }^{3}$, S.S. Desai ${ }^{1}$, M.P. Gavai ${ }^{2}$, \\ M.H. Keluskar ${ }^{2}$ and J.S. Dhekale ${ }^{4}$
}

${ }^{1}$ Department Agriculture Botany, ${ }^{2}$ RARS, Karjat, ${ }^{3}$ S.R.A, JSW-Tpp, Mango Project,

${ }^{4}$ Agriculture Economics, Dr. Balasaheb Sawant Konkan Krishi Vidyapeeth, Dapoli, India

*Corresponding author

\begin{tabular}{|c|c|}
\hline & A B S T R A C T \\
\hline $\begin{array}{l}\text { Hybrid Rice, } \\
\text { Oryza sativa } \mathrm{L}, \\
\text { Yield attributing } \\
\text { characters }\end{array}$ & \multirow{3}{*}{$\begin{array}{l}\text { Four male and three female parents, their twelve hybrids along with three standard checks } \\
\text { of rice (Oryza sativa L.) were evaluated during Kharif } 2016 \text { to study the nature and extent } \\
\text { of correlation among yield and yield attributing characters viz., days to } 50 \text { per cent } \\
\text { flowering, days to maturity, productive tillers plant }{ }^{-1} \text {, plant height }(\mathrm{cm}) \text {, panicle length } \\
(\mathrm{cm}) \text {, total spikelets panicle } \mathrm{e}^{-1} \text {, fertile spikelets panicle } \mathrm{e}^{-1} \text {, spikelet fertility }(\%), 1000 \text { grain } \\
\text { weight }(\mathrm{g}) \text {, grain yield plant }{ }^{-1}(\mathrm{~g}) \text {, straw yield plant }{ }^{-1}(\mathrm{~g}) \text { and harvest index }(\%) \text {. The results } \\
\text { revealed that grain yield plant }{ }^{-1} \text { to be positively and significantly associated with days to } \\
50 \text { per cent flowering }(0.988) \text {, days to maturity }(0.998) \text {, productive tillers plant }{ }^{-1}(0.849) \text {, } \\
\text { panicle length }(0.978) \text {, total spikelets panicle }{ }^{-1}(0.806) \text {, fertile spikelets panicle }{ }^{-1}(0.979) \\
\text { and straw yield plant }{ }^{-1}(0.719) \text { indicating importance of these traits as selection criteria in } \\
\text { yield improvement programmes. }\end{array}$} \\
\hline Article Info & \\
\hline $\begin{array}{l}\text { Accepted: } \\
\text { 10 March } 2019 \\
\text { Available Online: } \\
10 \text { April } 2019\end{array}$ & \\
\hline
\end{tabular}

\section{Introduction}

Rice (Oryza sativa L.) is staple food of more than $60 \%$ of Indian population. It accounts for about $43 \%$ of total food grain production and $46 \%$ of total cereal production in the country. Rice occupies pivotal place in Indian Agriculture. In order to meet the domestic demand of the increasing population the present day production of 107.40 million tons (Annonymous, 2015-16) of milled rice has to be increased to 125 million tons by the year 2030. Since the yield of high yielding varieties (HYVs) of rice is plateauing, it is rather difficult to achieve this target with the present day inbred varieties. Therefore, to sustain the self sufficiency in rice, additional production of 1.17 million tons is needed every year. At present, India has about 2.5 million hectares under hybrid rice cultivation of the total of 44 million hectares under rice cultivation (Ayyappan et al., 2012). The need for hybrid rice rapidly increasing population, plateauing yield trend of HYV's, declining resources (Viraktamath, 1997). To break the yield barriers in rice breeding strategies, attempts are being made. The grain yield is a complex character dependent on many 
component characters and it responds poorly to the direct selection. For the improvement of grain yield, the knowledge on the association between grain yield and its component characters will be helpful. The present study was, therefore, undertaken to understand the association among grain yield and its component characters Viraktamath, 1997).

\section{Materials and Methods}

The present study consists of $F_{1 s}$ along with parents and three standard checks of rice (Oryza sativa L.) procured from different sources. The present investigation was carried out at the Experimental farm of Regional Agriculture Research Station, Karjat (Raigad) during kharif 2016. The experimental trial was laid out in Randomized Block design with three replications. Three CMS lines viz., IR58025A, RTN 12A and RTN17A were crossed with four testers Chedo Local, CR2829-PLN-36, NPQ-49 and RP-5898-19-8-61-1-1 in a Line $\times$ Tester mating design developed 12 hybrids along with standard checks (Table 1). Data on the basis of 5 randomly taken competitive plants excluding borders were recorded on grain yield plant ${ }^{-1}$ $(\mathrm{g})$, straw yield plant ${ }^{-1}(\mathrm{~g})$, harvest index $(\%)$, plant height $(\mathrm{cm})$, number of productive tillers plant $^{-1}$, panicle length $(\mathrm{cm})$, total number of spikelets panicle ${ }^{-1}$, number of fertile spikelets panicle $^{-1}$, spikelet fertility (\%), 1000 grain weight $(\mathrm{g})$ while days to 50 per cent flowering and days to maturity were recorded on plot basis. The analysis was done as per Panse and Sukhatme (1985), Burton and De Vane (1953) and Johnson et al., (1955).

\section{Results and Discussion}

The analysis of variance for parents and hybrids was computed for different characters studied in Table 2. A study of various subdivisions of total variance elucidated the importance of variance due to parents and hybrids. The results revealed that the mean squares due to parents for all the characters were found significant except for productive tillers plant ${ }^{-1}$ and panicle length $(\mathrm{cm})$. The mean square values due to males were found to be highly significant for all the traits under study except number of productive tillers plant $^{-1}$ and panicle length $(\mathrm{cm})$. The mean square value due to females were found to be highly significant for all the traits under study except days to 50 per cent flowering, number of productive tillers plant ${ }^{-1}$ and panicle length $(\mathrm{cm})$. The mean square value due to males vs females were found to be highly significant for all the traits under study except number of productive tillers plant ${ }^{-1}$, panicle length $(\mathrm{cm})$ and grain yield plant $^{-1}(\mathrm{~g})$. The mean square values due to hybrids were found to be highly significant for all the traits under study except number of productive tillers plant ${ }^{-1}$. Similar results reported by Deepa Shankar et al., (2006) and Ravindra Babu et al., (2012). This indicated existence of considerable amount of genetic variability among parents and hybrids for all the traits under study.

In the present study, days to 50 per cent flowering exhibited a positive and significant association with days to maturity (0.999) (Debchoudhary and Das, 1998), number of productive tillers plant $^{-1}$ (0.756) (Sawant et al., 1995) and panicle length (0.933), total spikelets panicle ${ }^{-1}(0.888)$, fertile spikelets panicle $^{-1}$ (0.936) and grain yield plant ${ }^{-1}$ (0.988) (Yolanda and Vijendra Das, 1995) indicating a scope for simultaneous improvement of the traits. Similar results were reported by Deepa Sankar et al., (2006) and Singh et al., (2006). However, negative and significant association was noticed with spikelet fertility (-0.899), 1000 grain weight (0.990) and harvest index (-0.812). If one component gets advantage over the other, a negative correlation may arise (Adams and Grafius, 1971). 
Days to maturity had registered a positive and significant association with days to 50 per cent flowering (0.999), productive tillers plant $^{-1}$ (0.756) (Sawant et al., 1995), panicle length (0.933) (Singh et al., 1984) and total spikelets panicle ${ }^{-1}(0.888)$, fertile spikelets panicle $^{-1}(0.936)$, grain yield per plant (0.998) (Debchoudhary and Das, 1998).

However, negative significant associations were observed with plant height (0.500) and straw yield plant $^{-1}$ (0.603). Negative and significant associations were recorded for spikelet fertility $(-0.899), 1000$ grain weight (0.990) and harvest index (0.812). Similar results reported by Deepa Shankar et al., (2006) and Ravindra Babu et al., (2012).

Plant height had registered positive and significant associations with productive tillers plant $^{-1}$ (0.945), panicle length (0.778) and fertile spikelets panicle ${ }^{-1}$ (0.772) (Mirza et al., 1992; Chaubey and Singh, 1994; Nayak et al., 2001; Kole et al., 2008; Khan et al., 2009; Sadeghi, 2011; Ravindra Babu et al., 2012) and straw yield plant plant ${ }^{-1}$ (0.992). However, non-significant associations were noticed for the trait with days to maturity $(0.500)$ and grain yield plant plant ${ }^{-1}(0.629)$. Similar results reported by Deepa Shankar et al., (2006) and Ravindra Babu et al., (2012).

Productive tillers plant ${ }^{-1}$ showed positive and significant association with traits viz., panicle length (0.941), fertile spikelet's panicle ${ }^{-1}$ (0.938), straw yield plant (0.978), days to maturity (0.756) and grain yield plant $^{-1}$ (0.849). Similar results reported by Deepa Shankar et al., (2006) and Ravindra Babu et al., (2012).

Significant positive association was noticed for panicle length with fertile spikelets panicle $^{-1}(0.999)$, straw yield plant ${ }^{-1}(0.849)$, days to maturity (0.933) and grain yield plant ${ }^{1}$ (0.978) at genotypic level, while negative and significant association was recorded with 1000 grain weight (-0.872). However, it had recorded non significant association with total spikelets panicle ${ }^{-1}$ (0.664). Similar results reported by Mirza et al., (1992), Chaubey and Singh (1994), Nayak et al., (2001), Kole et al., (2008), Khan et al., (2009), Sadeghi (2011) and Ravindra Babu et al., (2012).

Total spikelets panicle ${ }^{-1}$ had exhibited negative and significant association with spikelet fertility (-0.999), 1000 grain weight ($0.945)$ and harvest index $(-0.989)$ while it had recorded positive significant association with days to maturity $(0.888)$ and grain yield plant ${ }^{-}$ ${ }^{1}$ (0.806).

Similar non-significant association of the trait with fertile spikelets panicle ${ }^{-1}(0.671)$ and straw yield plant ${ }^{-1}(0.0 .169)$ was reported earlier by Surek and Beser (2003) and Bagheri et al., (2011).

Positive significant association was noticed for fertile spikelets panicle ${ }^{-1}$ with days to 50 per cent flowering (0.936), plant height (0.772), productive tillers plant $^{-1}(0.938)$, panicle length (0.999), days to maturity (0.936), straw yield plant ${ }^{-1}(0.845)$ and grain yield plant $^{-1}$ (0.979), while it registered negative and significant association with 1000 grain weight (-0.876). Similar results reported by Mirza et al., (1992), Chaubey and Singh (1994), Nayak et al., (2001), Kole et al., (2008), Khan et al., (2009), Sadeghi (2011) and Ravindra Babu et al., (2012).

Spikelet fertility showed positive significant correlation with 1000 grain weight (0.952) and harvest index (0.986) while negative significant association was noticed with days to 50 per cent flowering $(-0.899)$, total spikelets panicle $^{-1}(-0.999)$, days to maturity ($0.899)$ and grain yield plant ${ }^{-1}(-0.819)$. Similar results reported by Deepa Shankar et al., (2006) and Ravindra Babu et al., (2012). 
Table.1 List of females, male lines, their hybrids along with standard checks

\begin{tabular}{|l|l|l|l|l|}
\hline Sr. No. & CMS Lines & Restorer Lines & Hybrids & Standard Checks \\
\hline $\mathbf{1}$ & IR58025A & Chedo Local & IR58025A x Chedo Local & Karjat-7 \\
\hline $\mathbf{2}$ & RTN12A & CR-2829-PLN-36 & IR58025A x CR-2829-PLN-36 & Sahyadri-2 \\
\hline $\mathbf{3}$ & RTN17A & NPQ-49 & IR58025A x NPQ-49 & Sahyadri-3 \\
\hline $\mathbf{4}$ & & RP-5898-19-8-6-1-1-1 & IR58025A x RP-5898-19-8-6-1-1-1 & \\
\hline $\mathbf{5}$ & & & RTN12A x Chedo Local & \\
\hline $\mathbf{6}$ & & & RTN12A x CR-2829-PLN-36 & \\
\hline $\mathbf{7}$ & & & RTN12A x NPQ-49 & \\
\hline $\mathbf{8}$ & & & RTN12A x RP-5898-19-8-6-1-1-1 & \\
\hline $\mathbf{9}$ & & & RTN17A x Chedo Local & \\
\hline $\mathbf{1 0}$ & & & RTN17A x CR-2829-PLN-36 & \\
\hline $\mathbf{1 1}$ & & & RTN17A x NPQ-49 & \\
\hline $\mathbf{1 2}$ & & & RTN17A x RP-5898-19-8-6-1-1-1 & \\
\hline
\end{tabular}

Table.2 Analysis of variance in Line x Tester analysis for twelve characters in rice (Oryza sativa L.)

\begin{tabular}{|c|c|c|c|c|c|c|c|c|c|c|c|c|c|}
\hline \multirow[t]{2}{*}{ Source of variation } & \multirow[b]{2}{*}{ DF } & \multicolumn{12}{|c|}{ Characters } \\
\hline & & $\begin{array}{l}\text { Days to } 50 \\
\text { per cent } \\
\text { Flowering }\end{array}$ & $\begin{array}{c}\text { Plant } \\
\text { Ieight }(\mathrm{cm})\end{array}$ & $\begin{array}{l}\begin{array}{c}\text { Product } \\
\text { ive } \\
\text { Tillers } \\
\text { Plant }^{-1}\end{array} \\
\text {. }\end{array}$ & $\begin{array}{c}\text { Panicle } \\
\text { Length } \\
\text { (cm) }\end{array}$ & $\begin{array}{c}\text { Total } \\
\text { Spikelets } \\
\text { Panicle }^{-1}\end{array}$ & $\begin{array}{c}\text { Fertile } \\
\text { Spikelets } \\
\text { Panicle }^{-1}\end{array}$ & $\begin{array}{c}\text { Spikelet } \\
\text { Fertility } \\
(\%)\end{array}$ & $\begin{array}{c}1000 \\
\text { Grain } \\
\text { Weight } \\
\text { (g) }\end{array}$ & $\begin{array}{l}\text { Grain } \\
\text { Yield } \\
\text { Plant }^{-1} \\
\text { (g) }\end{array}$ & $\begin{array}{c}\text { Straw } \\
\text { Yield } \\
\text { Plant }^{-1} \\
\text { (g) }\end{array}$ & $\begin{array}{c}\text { Harvest } \\
\text { Index } \\
(\%)\end{array}$ & $\begin{array}{c}\text { Days to } \\
\text { Maturit } \\
y\end{array}$ \\
\hline Replication & 2 & 0.018 & 7.78 & 1.31 & 0.36 & 92.57 & 49.42 & 5.14 & 0.025 & 0.14 & 0.36 & 0.40 & 0.018 \\
\hline Parents & 6 & $5.38^{* *}$ & $370.27^{* *}$ & 0.79 & 0.39 & $445.97^{* *}$ & $370.02^{* *}$ & $31.23^{* *}$ & $9.15^{* *}$ & $6.22^{* *}$ & $88.1^{* *}$ & $6.60^{* *}$ & $5.38^{* *}$ \\
\hline Male & 3 & $9.33^{* *}$ & $326.52^{* *}$ & 0.83 & 0.67 & $722.92^{* *}$ & $298.51^{* *}$ & $39.64^{* *}$ & 2.27 & 3.44 & $122.2^{* *}$ & $57.56^{* *}$ & $9.33^{* *}$ \\
\hline Female & 2 & 1.00 & $36.00^{* *}$ & 0.05 & 0.12 & $22.46^{* *}$ & 9.00 & $5.75^{* *}$ & $4.78 * *$ & $13.09^{* *}$ & 6.88 & $3.21^{* *}$ & 1.01 \\
\hline Male vs Female & 1 & $2.28 * *$ & $1170^{* *}$ & 2.15 & 0.09 & $462.13^{* *}$ & $1306.61^{* *}$ & $56.96^{* *}$ & $38.5^{* *}$ & 0.82 & $148.1^{* *}$ & $77.19^{* *}$ & 2.27 \\
\hline Hybrids & 11 & $54.45^{* *}$ & $107.38^{* *}$ & 1.15 & $8.55^{* * *}$ & $85.67^{* *}$ & $234.96^{* *}$ & $19.08^{* *}$ & $4.74 * *$ & $63.25^{* *}$ & $55.15^{* *}$ & $4.48 * *$ & $54.46^{* *}$ \\
\hline Parents vs. Hybrids & 1 & $102.92^{* *}$ & $7.86^{* *}$ & $154.54^{*}$ & $112.6^{* *}$ & $2725.1^{* *}$ & $9036.16^{* *}$ & $359.4^{* *}$ & $87.15^{* *}$ & $838.3^{* *}$ & $221.1^{* *}$ & $206.56^{* *}$ & $102.91^{* *}$ \\
\hline Error & 36 & 3.24 & 18.58 & 0.71 & 1.07 & 87.03 & 50.65 & 2.64 & 0.54 & 5.17 & 4.14 & 6.47 & 3.25 \\
\hline
\end{tabular}


Table.3 Correlation matrix showing close association between twelve quantitative characters of rice (Oryza sativa L.).

\begin{tabular}{|c|c|c|c|c|c|c|c|c|c|c|c|c|}
\hline Characters & $\begin{array}{l}\text { Days } 50 \\
\text { per cent } \\
\text { Flowering }\end{array}$ & $\begin{array}{c}\text { Plant } \\
\text { Height } \\
\text { (cm) }\end{array}$ & $\begin{array}{c}\text { Productive } \\
\text { Tillers } \\
\text { plant }^{-1}\end{array}$ & $\begin{array}{c}\text { Panicle } \\
\text { Length } \\
\text { (cm) }\end{array}$ & $\begin{array}{c}\text { Total } \\
\text { Spikelets } \\
\text { Panicle }^{-1}\end{array}$ & $\begin{array}{c}\text { Fertile } \\
\text { Spikelets } \\
\text { Panicle }^{-1}\end{array}$ & $\begin{array}{c}\text { Spikelet } \\
\text { Fertility } \\
\quad(\%)\end{array}$ & $\begin{array}{c}1000 \\
\text { Grain } \\
\text { Weight } \\
\text { (g) }\end{array}$ & $\begin{array}{c}\text { Straw } \\
\text { Yield } \\
\text { Plant } \\
1 \text { (g) }\end{array}$ & $\begin{array}{c}\text { Harvest } \\
\text { Index } \\
(\%)\end{array}$ & $\begin{array}{l}\text { Days to } \\
\text { Maturity }\end{array}$ & $\begin{array}{c}\text { Grain } \\
\text { Yield } \\
\text { Plant } \\
{ }^{1} \text { (g) }\end{array}$ \\
\hline $\begin{array}{l}\text { Days } 50 \% \\
\text { Flowering }\end{array}$ & 1.000 & & & & & & & & & & & \\
\hline $\begin{array}{l}\text { Plant Height } \\
\text { (cm) }\end{array}$ & 0.500 & 1.000 & & & & & & & & & & \\
\hline $\begin{array}{l}\text { Productive } \\
\text { Tillers plant }^{-1}\end{array}$ & $0.756^{*}$ & $0.945 * *$ & 1.000 & & & & & & & & & \\
\hline $\begin{array}{l}\text { Panicle Length } \\
\text { (cm) }\end{array}$ & $0.933 * *$ & $0.778 *$ & $0.941 * *$ & 1.000 & & & & & & & & \\
\hline $\begin{array}{l}\text { Total Spikelets } \\
\text { Panicle }^{-1}\end{array}$ & $0.888 * *$ & 0.047 & 0.371 & 0.664 & 1.000 & & & & & & & \\
\hline $\begin{array}{l}\text { Fertile Spikelets } \\
\text { Panicle }^{-1}\end{array}$ & $0.936 * *$ & $0.772 *$ & $0.938 * *$ & $0.999 * *$ & 0.671 & 1.000 & & & & & & \\
\hline $\begin{array}{l}\text { Spikelet Fertility } \\
(\%)\end{array}$ & $-0.899 * *$ & -0.069 & -0.392 & -0.681 & $-0.999 * *$ & -0.687 & 1.000 & & & & & \\
\hline $\begin{array}{l}1000 \text { Grain } \\
\text { Weight (g) }\end{array}$ & $-0.990 * *$ & -0.371 & -0.655 & $-0.872 *$ & $-0.945 * *$ & $-0.876^{*}$ & $0.952 * *$ & 1.000 & & & & \\
\hline $\begin{array}{l}\text { Straw Yield } \\
\text { Plant }^{-1} \text { (g) }\end{array}$ & 0.603 & $0.992 * *$ & $0.978 * *$ & $0.849 *$ & 0.169 & $0.845^{*}$ & -0.191 & -0.482 & 1.000 & & & \\
\hline $\begin{array}{l}\text { Harvest Index } \\
(\%)\end{array}$ & $-0.812 *$ & 0.099 & -0.232 & -0.548 & $-0.989 * *$ & -0.555 & $0.986 * *$ & $0.887 *$ & -0.024 & 1.000 & & \\
\hline Days to Maturity & $0.999 * *$ & 0.500 & $0.756^{*}$ & $0.933 * *$ & $0.888^{*}$ & $0.936 * *$ & $\begin{array}{c}- \\
0.899 * *\end{array}$ & ${ }^{-}-$ & 0.603 & $-0.812 *$ & 1.000 & \\
\hline $\begin{array}{l}\text { Grain Yield } \\
\text { Plant }^{-1} \text { (g) }\end{array}$ & $0.988 * *$ & 0.629 & $0.849 *$ & $0.978 * *$ & $0.806^{*}$ & $0.979 * *$ & $-0.819 *$ & $\begin{array}{c}- \\
0.955^{* *}\end{array}$ & $0.719 *$ & $-0.712 *$ & $0.998 * *$ & 1.000 \\
\hline
\end{tabular}


Positive significant association was noticed for 1000 grain weight with spikelet fertility (0.952) and harvest index (0.887) while negative significant association was noticed with days to 50 per cent flowering (-0.990), panicle length (-0.872), total spikelets panicle $^{-1}(-0.945)$, fertile spikelets panicle ${ }^{-1}$ ($0.876)$, days to maturity (-0.990) and grain yield plant ${ }^{-1}(-0.955)$. Similar results reported by Mirza et al., (1992), Chaubey and Singh (1994), Nayak et al., (2001), Kole et al., (2008), Khan et al., (2009), Sadeghi (2011) and Ravindra Babu et al., (2012).

Straw yield plant ${ }^{-1}$ showed positive significant with plant height $(0.992)$, productive tillers plant $^{-1}$ (0.978), panicle length (0.849), fertile spikelets panicle $^{-1}$ (0.845) (Nayak et al., 2001 and Nayak and Reddy, 2005) and grain yield per plant ${ }^{-1}(0.719)$. Similar results reported by Deepa Shankar et al., (2006) and Ravindra Babu et al., (2012).

Positive significant association was noticed for harvest index with spikelet fertility (0.986) and 1000 grain weight $(0.887)$ while negative and significant association was recorded with days to 50 per cent flowering $(-0.812)$, total spikelets panicle ${ }^{-1}(-0.989)$, days to maturity ($0.812)$ and grain yield plant ${ }^{-1}(-0.712)$, similar to the findings of Sadeghi (2011).

A perusal of the results on character associations for grain yield, yield components and quality characters revealed phenotypic and genotypic correlation to be of similar direction and significance. The genotypic correlation values were also in general higher than the phenotypic correlation values indicating the masking effects of environment on these traits (Table 3). Similar results were reported by Rajput et al., (1996). Grain yield plant $^{-1}$ was observed to be positively and significantly associated with days to 50 per cent flowering, days to maturity, productive tillers plant $^{-1}$, panicle length, total spikelets panicle $^{-1}$, fertile spikelets panicle ${ }^{-1}$ and straw yield plant $^{-1}$ indicating the importance of these traits as selection criterion in yield enhancement programmes. The results are in line with the findings of Nayak et al., (2001) and Nayak and Reddy (2005).

\section{Acknowledgement}

We thankful to the Head, Scientists, Professors and technical staff, Department of Agriculture Botany, College of Agriculture, Dapoli and RARS, Karjat, Dr. B. S. K. K. V., Dapoli for their valuable assistance.

\section{References}

Adams, M.W and Grafius, J.E. 1971. Yield components compensation: alternative interpretation. Crop Science. 11 pp: 3335.

Akhtar, N., Nazir, M.F., Rabnawaz, A., Mahmood, T., Safdar, M.E., Asif, M and Rehman, A. 2011. Estimation of heritability, correlation and path coefficient analysis in fine grain rice. The Journal of Animal \& Plant Sciences. 21 (4) pp: 660-664.

Anonymous, (2015-16). Directorate of Economics and Statistics, DAC and FW, GOI.

Ayyappan, S. Long Ping Yuan, B. C. Viraktamath, Kanna Lakshminarayana and Robert S. Zeigler (2012). $6^{\text {th }}$ International Rice Genetics Symposium held in Hyderabad during 10-12 September, 2012. pp: 57-59.

Bagheri, N., Jelodar, B.N and Pasha, A. 2011. Path coefficient analysis for yield and yield components in diverse rice genotypes. Biharean Biologist. 5 (1) pp: 32-35.

Burton, G.W and Dervane, E.H. (1953). Estimating heritability in tall fescue (Festuca arundinaceae) from replicated clonal material. Agron. J. 45 pp: 478- 
481.

Chaubey, P.K and Singh, R.P. 1994. Genetic variability, correlation and path analysis of yield components in rice. Madras Agril. J. 81 (9) pp: 468-470.

Debchoudhury, P.K and Das, P.K. (1998). Genetic variability, correlation and path coefficient analysis in deep water rice. Annals of Agric. Res. 19 pp: 120-124.

Deepa Sankar, P., Sheeba, A and Anbumalarmathi, J. 2006. Variability and character association studies in rice. Agric. Sci. Digest. 26 (3) pp: 182-184.

Johnson, H.W., Robinson, H.E and Comstock, R.E. (1955). Estimates of genetic and environmental variability in soybean. Agron. J. 47 pp: 314-318.

Khan, A.S., Imran, M and Ashfaq, M. 2009. Estimation of genetic variability and correlation for grain yield components in rice. American-Eurasian J. Agric. \& Environ. Sci. 6 (5) pp: 585-590.

Kole, P.C., Chakarborty, N.R and Bhat, J.S. 2008. Analysis of variability, correlation and path coefficients in induced mutants of aromatic nonbasmati rice. Trop. Agric. Res. Exten. 113 pp: 60-64.

Mirza, M.J., Faiz, F.A and Mazid, A. 1992. Correlation and path analysis of plant height, yield and yield components in rice. Sarhad J. Agril. 8 pp: 647-653.

Nayak, A.R and Reddy, J.N. 2005. Seasonal influence on quality characters in scented rice. Indian Journal of Genetics and Plant Breeding. 65 (2) pp: 127-128.

Nayak, A.R., Chaudhury, D and Reddy, J.N. 2001. Correlation and path analysis in scented rice. Indian J. Agric. Res. 35 (3) pp: 186-189.

Panse, V.G and Sukhatme, P.V. 1985. Statistical methods for agricultural workers. Indian Council of Agricultural Research, New Delhi.

Rajput, J.C., Pandit, S.S., Patil, S.S and Patil, V.H. (1996). Variability, heritability and inter-relationship of important quantitative characters in Brinjal. Annals Agric. Res. 17 pp: 235-240.

Ravindra Babu, V., Shreya, K., Kuldeep Singh Dangi, Usharani, $G$ and Siva Shankar, A. 2012. Correlation and path analysis studies in popular rice hybrids of India. International Journal of Scientific and Research Publications. 2 (3) pp: 1-5.

Sadeghi, S.M. 2011. Heritability, phenotypic correlation and path coefficient studies for some agronomic characters in land race rice varieties. World Applied Sciences Journal. 13 (5) pp: 1229-1233.

Sawant, D.S., Patil, S.L., Sadhar, B.B and Bhare, S. G. (1995). Genetic divergence, character association and path analysis in rice. J. Maharashtra agric. Univ. 20 pp: 412-414.

Seyoum, M., Alamerew, S and Bantte, K. 2012. Genetic variability, heritability, correlation coefficient and path analysis for yield and yield related traits in upland rice. Journal of Plant Sciences. 7 (1) pp: 13-22.

Viraktmath, B. C. (1997). Hybrid Rice Breeding Manual. IRRI Los Banos, Laguna, Philippines $1^{\text {st }}$ Ed.

\section{How to cite this article:}

Thorat, B.S., R.L. Kunkerkar, S.M. Raut, S.S. Desai, M.P. Gavai, M.H. Keluskar and Dhekale, J.S. 2019. Correlation Studies in Hybrid Rice (Oryza sativa L.). Int.J.Curr.Microbiol.App.Sci. 8(04): 1158-1164. doi: https://doi.org/10.20546/ijcmas.2019.804.133 